\title{
Giving Belly Breathing Technique and Positive Affirmation of Stress and Cortisol Hormone Lev- els in Third Trimester Pregnant Women
}

\author{
Annisa Septy Nurcahyani ${ }^{1}$, Runjati $^{2}$, Sri Achadi Nugraheni ${ }^{3}$ \\ \{annisaseptyn@gmail.com ${ }^{1}$, runjati@yahoo.com ${ }^{2}$, s.a.nugraheni.undip@gmail.com ${ }^{3}$ \} \\ Poltekkes Kemenkes Semarang, Semarang, Indonesia ${ }^{1,2,3}$
}

\begin{abstract}
During pregnancy the mother has mood changing or increased anxiety which can make the mother stressed. Belly breathing techniques and positive affirmations can be an alternative for pregnant women to reduce stress levels. The design of this study was a quasi experiment with a non randomized pretest posttest with control group design. A total of 40 respondents domiciled around Public Health Center of Kalimanah, Padamara, and Purbalingga were divided into intervention and control groups. Stress level evaluated with DASS-42 and cortisol evaluated with serum blood $(3 \mathrm{cc})$. The p-value (wilcoxon) before and after the treatment showed the treatment of belly breathing techniques and positive affirmation can affect stress and cortisol in the pregnant women significantly. Belly breathing techniques and positive affirmations can be suggested to be material in the class of pregnant women so the pregnant woman more calm, more comfortable, has a positive and confident during her pregnancy.
\end{abstract}

Keywords: belly breathing, positive affirmations, stress, cortisol

\section{Introduction}

During pregnancy, some pregnant women has psychological or mental changing [1]. Pregnancy woman has stress because of unbalance estrogen and progesterone hormones that can make uncomfort pregnancy such as mood swing, anxiety, fear and panic [2-4]. Stress is triggered by the mother's concern about her condition such as fear of miscarriage, fetal development is not appropriate, fear of labor, fear of not being able to normal delivery, too often hear negative experiences other people's and pain during deliver the baby $[1,5]$.

Stress is a condition where the body's response is not specific to anything [6]. Stress affects a person's psychology, nervous system, endocrine and immune system [7]. Stress in pregnant women can affect the baby, depression during the puerperium and increase high blood pressure [8,9]. In the world, the incidence of high blood pressure during pregnancy is around 10\% [10] whereas in Indonesia, high blood pressure 
in pregnant women has $27.1 \%$ [11]. High blood pressure in pregnant women increases the risk of preeclampsia and eclampsia [12]. In addition, stress causes the mother to have insomnia.

Some factors can cause stress of pregnant women such as worries, have negative thoughts about themselves, worrying care for babies properly and having negative recordings because they often hear fear stories of labor [1,2]. Stress in pregnant woman will produce corticotropin in hypothalamus and stimulate the production of adrenocortopin and release cortisol $[8,13]$. Non-pharmacological therapies can help pregnant women reduce their stress levels include pregnancy exercise, prenatal yoga, listening Al-Qur'an murotal and SEFT (Spiritual Emotional Freedom Technique) [4]. However, there are other therapies such as relaxation of breath and positive affirmations can be alternative for pregnant women to reduce stress levels. According to Ilmiasih research, pregnant women will relax and comfortable, reduce anxiety when practice breathing relaxation and positive affirmations to themselves consistently. When relaxed, the body releases serotonin hormones and endorphins, so all nervous system balance [3].

\section{Materials and methods}

Research in this study use quasi experiment with a non-randomized pretest posttest with control group design. Subject was chosen based on the criteria of the researcher, sample was taken by non-randomized sampling method, purposive sampling technique and after the subject was selected, the researcher divided respondents into control and intervention group.

This research was conducted in Kalimanah, Padamara, Purbalingga Public Health Center working area. Respondents in this study were pregnant women 20 - 35 years old, 28-36 weeks gestational age. Measurement of stress levels using Depression Anxiety Stress Scale (DASS 42) questionnaire. DASS 42 consists of 42 question items covering three sub-variables physical, emotional and behavioral. Based on Cronbach's Alpha DASS 42 has a value of validity and reliability of 0.91. Stress categories in DASS 42 are divided into five categories: normal, mild, moderate, severe and very severe. Measurement of respondent's serum cortisol level was stored and analyzed in the laboratory of GAKI Faculty of Medicine, Diponegoro University, Semarang.

Researchers gave intervention belly breathing techniques and positive affirmations 4 times in 2 weeks with 20 minutes duration. Intervention group receive belly breathing techniques, positive affirmations and counseling, information education, while the control group only get counseling, information and education. 


\section{Results}

\subsection{Giving Belly Breathing Technique and Positive Affirmation of Stress in Pregnant Women}

Based on results in this research pre-intervention average of stress level 16.70 and control group 15.85. Post intervention averaged 8.15 and control group 15.15. Stress levels in intervention and control groups decreased, p-value (wilcoxon) before and after treatment of belly breathing techniques and positive affirmations have $<0.05$, it means there are significant differences before and after treatment of belly breathing techniques and positive affirmation.

Table 1. Giving Belly Breathing Technique and Positive Affirmation of Stress in Pregnant Women

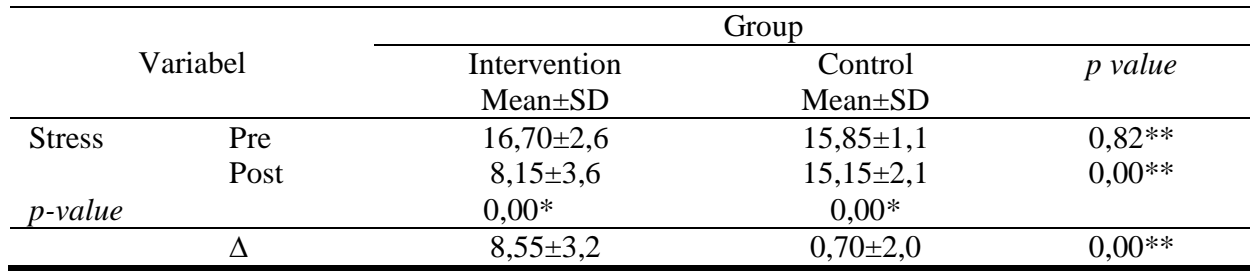

*Wilcoxon

**Mann Whitney

\subsection{Giving Belly Breathing Technique and Positive Affirmation of Cortisol} Hormone Levels in Pregnant Women

Based on result of cortisol hormone levels is 136.95 for pre intervention and 111.40 for post intervention, while control group pre-intervention was 111.15 and 104.50 for post intervention. The $\mathrm{p}$ value (wilcoxon) before and after treatment of belly breathing techniques and positive affirmations have a value $<0.05$, it means concluded that there are significant differences before and after treatment of belly breathing techniques and positive affirmation of cortisol hormone.

Table 2. Giving Belly Breathing Technique and Positive Affirmation of Cortisol Hormone Levels in Pregnant Women

\begin{tabular}{lcccc}
\hline & & \multicolumn{3}{c}{ Group } \\
\cline { 3 - 5 } & Variabel & Intervention & Control & $p$ value \\
& & Mean \pm SD & Mean \pm SD & \\
\hline Cortisol & Pre & $136,9 \pm 37,0$ & $111,4 \pm 74,0$ & $0,82^{* *}$ \\
& Post & $111,1 \pm 27,1$ & $104,5 \pm 66,0$ & $0,00^{* *}$ \\
p-value & & $0,00^{*}$ & $0,00^{*}$ & \\
& $\Delta$ & $25,8 \pm 23,1$ & $6,9 \pm 25,3$ & $0,00^{* *}$ \\
\hline
\end{tabular}

*Wilcoxon

**Mann Whitney 


\section{Discussions}

\subsection{Giving Belly Breathing Technique and Positive Affirmation of Stress in Pregnant Women}

Based on results in this study, belly breathing techniques and positive affirmations 4 times in 2 weeks with a duration of 20 minutes in pregnant women can affect stress levels of pregnant women. The p-value (wilcoxon) before and after treatment belly breathing techniques and positive affirmations have a value $<0.05$, so it means concluded that there are significant differences before and after treatment of belly breathing techniques and positive affirmation of stress. Mann Whitney test results on the two groups in pre-test obtained 0.820 results which can be interpreted there is no difference between the two groups before treatment and the results of post-test results obtained 0,000 which means there is a difference between the two groups after treatment.

Pregnancy causes many physical and psychological changes; this is due to hormonal changes in pregnant women. Psychological changes such as worry by changes in body shape, worry that the fetus is born in abnormal condition, fear, anxiety and stress. Family support internally and externally can cause pregnant women to worry excessively, fear and stress, especially the third trimester because mother and family wait the baby [14].

Belly breathing teaches pregnant women to breathe deeply and exhale slowly [15]. Belly breathing takes maximum air and toxins from the lungs and helps oxygen to the lungs. When breathing deeply and regularly, breathing will slower so pulse and heart beat also decrease [16]. Belly breathing increase alveoli ventilation, reduce stress both physically and emotionally which can help reduce pain and anxiety [15]. Results of this study showed the group given belly breathing techniques decreased stress in the intervention group. This means that the breathing relaxation technique can maximize oxygen entering the lungs, make breathing slow and reduce stress in pregnant women. Stress in pregnant women caused by physical factors such as forced physical exercise, sound environmental conditions, air pollution, temperature, radiation, food consumed, additives and trauma [17]. Besides the source stress is also obtained from daily problems [18]. Same with Makwa and Hidayati's research that breathing relaxation helps reduce stress levels, makes the body more comfortable and reduces negative emotions [19].

Besides belly breathing techniques researchers also gave positive affirmations to pregnant women. According to Dr. Carmen Harra clinical psychological expert, positive affirmations can affect the universe, when word comes out in the form of sound, waves to the universe, penetrate the air and become real. When speaking "I am healthy" universe will give the ability to do that. Affirmations can affect the subconscious mind and give suggestions to yourself [14].

Researchers gave positive affirmations such as "My pregnancy is healthy", "Strong membranes", "Placenta healthy", "Smooth delivery", "When the contraction came, I always smile" with the aim of giving positive energy to pregnant women to reduce anxiety and stress. The results of this study mention the intervention group greater reduction than control group who have not positive affirmation treatment. Accordance of Indrayani and Sumarni's research, self-affirmation is effective to re- 
duce level of anxiety that can cause stress in the mother, positive thoughts can expedite blood flow so that stress can be reduced [20].

\subsection{Giving Belly Breathing Technique and Positive Affirmation of Cortisol Hormone Levels in Pregnant Women}

Based on results of this study the p-value (wilcoxon) before and after the treatment of belly breathing techniques and positive affirmations $<0.05$. Mann Whitney test results on the two groups in pre-test showed 0.010 results which can be interpreted that there are differences between the two groups before treatment and the results of the post-test results obtained 0.149 which means there is no difference between the two groups after treatment, so it can be concluded that there are differences significant between the two groups after being given an intervention.

Relaxation during pregnancy significantly reduce stress levels in pregnant women by blood pressure, pulse, decreased cortisol levels [21]. High cortisol hormone levels in the body can affect immune system, brain memory disorders, depression, osteoporosis, high blood pressure and insulin resistance [22]. Belly breathing technique is one of the relaxation techniques can be performed by pregnant women.

Belly breathing techniques and positive affirmations was given 4 times in 2 weeks with a duration of 20 minutes in pregnant women affect cortisol hormone levels in pregnant women. Results of Lestari's, Ahmad and Prasanto research doing deep breathing routinely can help lower blood pressure and helps reduce cortisol levels in the body [23]. Belly breathing can improve the parasympathetic system, provide a calming effect and stimulate the release of oxytocin and reducing cortisol [24].

The results showed that there were differences in cortisol hormone levels before being given an intervention and there was no difference after being given an intervention, there was a selective decrease but it was possible not because of the intervention given. Based on research Maulia and Ambarwati breath relaxation 3 times a day with a duration of 15 minutes can reduce blood sugar levels so that stress decreases and affects cortisol hormone levels [25]. In this study the breathing technique was only carried out for 10 minutes. Less intense duration may be one of the factors causing a significant decrease in cortisol.

Positive affirmations are affirmation to yourself to get rid of negative beliefs that exist in the subconscious mind [26]. Positive affirmations prepared for pregnant women to have physical and mental health which motivating, inspiring, providing support, changing perspectives, affecting the body, soul and mind to become daily behavior [27]. Andriyani research results, positive affirmations help reduce tension, sleep more soundly, stay relaxed, reduce feelings of worry about bad things so that the brain center of emotions (hypothalamus) control neuroendocrine, including cortisol [28]. Although the results of this study have not shown a significant decrease in cortisol hormone levels, other references continue positive emotional responses, a calmer self will make the hypothalamus decrease CRF secretion, a decrease in CRF stimulates a decrease in ACTH and has an effect on decreasing cortisol secretion [29].

Cortisol regulation can be improved when opioids, serotonin and GABA in amygdala be regulated by the activity limbic system that affected by positive affirmations, so pregnant woman feeling comfortable [14]. This is different with the results of this study where cortisol levels have not dropped significantly, this is possible 
when giving positive affirmations that pregnant women are not focused and not affected limbic system in the amygdala (cortisol) [30].

\section{Conclusion}

Based on the results of this research belly breathing techniques and positive affirmations have effect on stress and cortisol hormone levels in pregnant women, it can be concluded that belly breathing techniques and positive affirmations 4 times in 2 weeks with a duration of 20 minutes effect on stress reduction and cortisol levels in pregnant women. Researchers combine other non-pharmacological interventions, increasing the duration of intervention to make it more effective in reducing stress and cortisol levels in pregnant women.

\section{References}

[1] Aziz NA, Margaretha. Strategi Coping Terhadap Kecemasan Pada Ibu Hamil dengan Riwayat Keguguran di Kehamilan Sebelumnya. J Ilm Psikol Terap. 2017;05:200.

[2] Kuswandi L. Hypnobirthing: A Gentle Way to Give Birth. Jakarta: Pustaka Bunda; 2013.

[3] Ilmiasih R. Pengaruh Teknik Hypnorbirthing Terhadap Tingkat Kecemasa Ibu Hamil Pada Masa Persiapan Menghadapi Persalinan. 2017;93-100.

[4] Susilowati T, Pramana N, Muis SF. Non-Pharmacological Intervention on Anxiety Primigravida. J Ilm Permas J STIKES Kendal. 2019;9:181-6.

[5] Larasati IP, Wibowo A. Pengaruh Keikutsertaan Senam Hamil Terhadap Kecemasan Primigravida Trimester Ketiga Dalam Menghadapi Persalinan. J Biometrika dan Kependud. 2012;1:26-32.

[6] Fink G. Stress : Concepts Definition, History. Ref Modul Neurosci Biobehav Psychol. 2016;

[7] Perciavalle V, Blandini M, Fecarotta P, Buscemi A, Di Corrado D, Bertolo L. The Role of Deep Breathing on Stress. Neurol Sci. 2017;38:451-8.

[8] Chen PJ, Yang L, Chou CC, Li CC, Chang YC, Liaw JJ. Effects of Prenatal Yoga on Women's Stress and Immune Function Across Pregnancy: A randomized Controlled Trial. Complement Ther Med. Elsevier Ltd; 2017;31:109-17.

[9] Corbijn van Willenswaard K, Lynn F, McNeill J, McQueen K, Dennis CL, Lobel M. Music interventions to reduce stress and anxiety in pregnancy: A systematic review and meta-analysis. BMC Psychiatry. BMC Psychiatry; 2017;17:1-9.

[10] Magee LA, Von Dadelszen P, Rey E, Ross S, Asztalos E, Murphy KE. Less-tight versus tight control of hypertension in pregnancy. N Engl J Med. 2015;372:407-17.

[11] Lombo G, Wagey F, Mamengko L. Observations of Control System Design: Problems and Promise. J Kedokt Klin. 2017;1:9-15.

[12] Kaimmudin L, Pangemanan D, Bidjuni H. Hubungan Usia Ibu Saat Hamil Dengan Kejadian Hipertensi Di RSU GMIM Pancaran Kasih Manado. J Keperawatan. 2018;6:15.

[13] Primawati AS, Widyawati MN, Admini A. Penurunan Tingkat Stres Ibu Hamil Dengan Terapi Musik Dan Aromatherapy Pada Kelas Ibu Hamil. J Kebidanan. 2018;8:37.

[14] Cholifah N, Fahrida R, Hartinah D. Pengaruh Pemberian Afirmasi Positif Terhadap Perubahan Psikologis Ibu Hamil dengan Pre Eklampsia di Klinik Kandungan RSUD RA Kartini Kabupaten Jepara Tahun 2017. Indones J Perawat. 2017;2:80-6.

[15] Irawan FD, Sudiwati NLPE, Dewi N. Perbandingan Tekhnik Relaksasi Nafas Dalam dan Kompres Dingin Terhadap Penurunan Tingka Nyeri haid (Dismenore) Pada Mahasiswi di 
Asrama Sanggau dan Ikatan Keluarga Belu di Landungsari Kota Malang. Nurs News (Meriden). 2016;1:358-68.

[16] Yoga TTPG. Modul Prenatal Gentle Yoga. PT Kristala Permata Nusantara; 2018.

[17] Rahmayani MP, Rohmatin E, Wulandara Q. Pengaruh Terapi Murotal Al-Qur'an Terhadap Tingkat Stres Pada Pasien Abortus di RSUD dr. Soekardjo Kota Tasikmalaya Tahun 2018. J Bidan "Midwife Journal." 2018;4:36-41.

[18] Lumban Gaol NT. Teori Stres: Stimulus, Respons, dan Transaksional. Bul Psikol. 2016;24:1.

[19] Makwa DJ, Hidayati E. Relaksasi Untuk Mengatasi Stres Sehari-hari Pada Lansia. Pros Temilnas XI IPII. 2019. p. 20-1.

[20] Indrayani T, Sumarni W. Efektivitas Afirmasi Tenaga Kesehatan Pada Tingkat Kecemasan Ibu Bersalin Multipara Di RSUD Bula Kabupaten Seram Bagian Timur Tahun 2018/2019. J Ilmu dan Budaya. 2019;41:7489-94.

[21] Septianingrum Y. Terhadap Penurunan Stres , Kecemasan. J Ilm Kesehat. 2015;8:206-12.

[22] Shopia, Seotriliyana N, Nuzulmi A. Efektivitas Pranayama Terhadap Penurunan Kecemasan Pada Ibu Hamil Trimester III. Pertem Ilm Nas Penelit dan Pengabdi Masy. 2018:1:432-9.

[23] Lestari ADP, Ahmad RA, Prasanto H. Efek Metode Deep Dan Afirmation Positif Pada Penurunan Tekanan Darah Pasien Hipertensi Di Kulon Progo. J Community Med Publik Heal. 2017; Vol. 33 No:1-6.

[24] Salafas E, Anisa; R, Rusita; VI. Efektivitas Hypno-Eft dan Pernafasan Yoga dalam Mernurunkan Kecemasan Ibu Hamil di BPM Ny. Sri Kustinah. 2016;7:84-94.

[25] Rizki Maulia I. Terapi Relaksasi Teknik Nafas Dalam ( Deep Breathing ) Dalam Menurunkan Kadar Gula. J Profesi Keperawatan. 2017;4:59-67.

[26] Yuwinten, Tajmiati A, Nurvita N. Pengaruh Komunikasi Afirmasi Terhadap Durasi Mual Muntah Ibu Hamil Trimster I Kecamatan Cibereum Kota Tasikmalaya Tahun 2018. J Kesehat Bakti Tunas Husada J Ilmu Keperawatan. 2018;18:237-48.

[27] Syaras D, Yasir Y, Wirman W. Komunikasi Intrapersonal Pasien Hypnobirthing Di Rumah Sakit Bersalin Annisa Pekanbaru. J Ris Komun. 2019;2:13-20.

[28] Andriyani A, Sulaeman JSJ, Marhaeni D. Kelas Hypnobirthing Sebagai Mind-Body and Interventions: Study Kualitatif Di Puskesmas Rawat Inap Kota Yogyakarta. J Ilmu Kebidanan. 2016;4:37-52.

[29] Lisdiana. Regulasi Kortisol Pada Kondisi Stres Dan Addiction. Biosaintifika J Biol Educ. $2012 ; 4$.

[30] Indonesia H. Modul Panduan Pelatihan Basic Hypnosis dan Hypnobirthing. Jakarta: PT Kristala Permata Nusantara; 2019. 